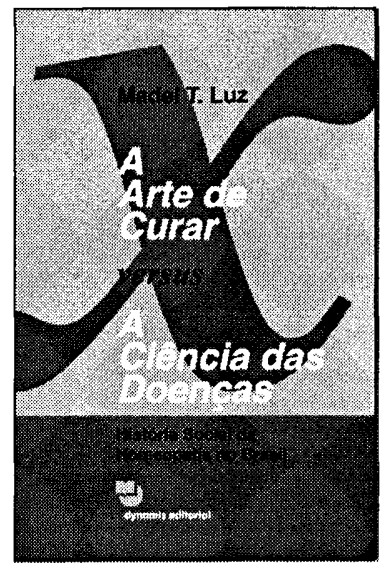

\title{
Entre a Ciência e a Cultura: O Caso da Homeopatia Brasileira
}

\author{
A Arte de Curar versus A Ciências das Doenças: História \\ Social da Homeopatia no Brasil - Madel T. Luz \\ São Paulo: Dynamis Editorial, 1996 \\ 342 páginas
}

\section{Luiz Otávio Ferreira}

Departamento de Pesquisa Histórica, Casa de Oswaldo Cruz, Fundação Oswaldo Cruz

Os estudos sobre a institucionalização da medicina no Brasil nos séculos XIX e XX têm sugerido a inexistência de movimentos alternativos que tivessem oferecido resistência à monopolização dos saberes e práticas relacionados à saúde por parte dos representantes da medicina científica. Ao contrário do que ocorreu, por exemplo, nos Estados Unidos da América do Norte, onde a institucionalização da medicina científica foi seriamente dificultada por um expressi- vo movimento de sistemas médicos heterodoxos e seitas curativas de cunho popular, no Brasil este tipo de resistência cultural teria sido difusa e não organizada.

A hegemonia da medicina científica, alcançada aparentemente sem nenhum conflito sóciocultural mais sério, é comumente atribuída ao caráter oficial que as instituições responsáveis pela produção e reprodução do saber médico tiveram no país descle suas origens, no início de século XIX. Como ór- gãos associados ao Estado, as instituições médicas estiveram, desde sempre, investidas de legalidade e isso parece ter sido suficiente para garantir, aos saberes e práticas relacionados à medicina científica, algo muito mais importante e decisivo que é a legitimidade social.

O mais recente livro de Madel T. Luz, A Arte de Curar versus $A$ Ciência das Doenças: História Social da Homeopatia no Brasil, oferece ao leitor a oportunidade de relativizar a idéia de que 
a hegemonia da medicina científica foi construída sem que a ela se opusesse nenhuma forma de resistência socialmente organizada. Além disso, ao estudar o longo processo de institucionalização da homeopatia focalizando suas estratégias de legitimação político-institucional e as contra-estratégias perpetradas pelos representantes da medicina oficial, Madel Luz desenvolve uma vigorosa reflexão a respeito de uma questão pouco explorada nos estudos sobre o processo de institucionalização da medicina em nosso país: as contradições entre a legalidade e a legitimidade social.

Os 150 anos que totalizam o longo percurso da homeopatia brasileira em busca da sua institucionalização foram divididos por Madel Luz em seis períodos analiticamente considerados conjunturas institucionais distintas, ou seja, momentos políticos decisivos para o avanço ou recuo do processo de legitimação da medicina homeopática. $\mathrm{O}$ primeiro deles, denominado periodo de implantação (1840-1859), foi a etapa inicial na qual os fundadores da homeopatia brasileira, através de uma articulada estratégia de propaganda e de formação de praticantes leigos, conseguiram fazer a medicina homeopática avançar rumo à sociedade civil, obtendo legitimidade perante diferentes grupos sociais, malgrado o bloqueio imposto pelos representantes da medicina oficial no que se refere à sua legalização perante o Estado.

A fase seguinte, denominada periodo de expansão $e$ resistência (1860-1882), caracterizou-se pela ampliação significativa da aceitação da medicina homeopática junto à sociedade civil, sobretudo entre os setores populares; fato que possibilitou a abertura de espaços institucionais (hospitais de ordens religiosas e militares), até então reservados exclusivamente à medicina alopática, à pratica da clínica homeopática. Ao mesmo tempo, crescia entre os médicos o número de adeptos da orientação que propugnava a incorporação da homeopatia à ordem médica oficial.

Seguiu-se o periodo de resistência (1882-1900), momento em que, apesar da popularidade dos homeopatas, registra-se o recuo institucional da homeopatia ocasionado pela rejeição categórica de sua pretensão de incorporação à ordem médica oficial.

O periodo áureo (19001930) é aquele que, na cronologia histórico-institucional proposta por Madel Luz, apresenta maior complexidade. É a fase em que os homeopatas alcançam seus maiores êxitos, conseguin- do não só aprofundar a aceitação popular da homeopatia, mas também conquistar finalmente a tão desejada oficialização e equiparação da medicina homeopática à medicina alopática. São então criadas faculdades, hospitais e ligas de orientação homeopática; fatos que foram interpretados como o reconhecimento do estatuto científico da homeopatia.

O quinto período da história da homeopatia no Brasil é o do declínio acadêmico da bomeopatia (1930-1970), fase em que os tradicionais embates entre homeopatas e alopatas dão lugar ao silêncio indicativo do crescente isolamento acadêmico da homeopatia, cada vez mais, vista como uma medicina superada. No entanto, a homeopatia se legitimava, paulatinamente, em outros espaços sociais distantes da academia, tais como os centros espíritas e terreiros de umbanda.

Finalmente, chegamos ao período da retomada social da bomeopatia (19701990), que marca o ressurgimento da homeopatia como uma medicina alternativa ao modelo médico dominante, atraindo novos seguidores na academia, expandindo sua esfera de aceitação na direção dos setores de classe média urbana e, principalmente, sendo integrada ao serviços públicos de 
saúde. De novo reacende-se o debate em torno do estatuto científico da homeopatia; debate do qual explicitamente faz parte o livro que aqui está sendo resenhado.
Da análise desenvolvida por Madel Luz, sobressai o dilema histórico dos homeopatas, divididos entre a busca obstinada da legalidade pelo caminho da integração ao campo acadêmico-científico e a aceitação popular resultante da incorporação sincrética da homeopatia ao universo da práticas populares de cura de caráter religioso. 